ELECTRON MICROSCOPY AND STRUCTURE OF MATERIALS 



\section{Electron Microscopy}

\section{and \\ Structure of Materials}

GARETH THOMAS, Editor

RICHARD M. FULRATH, Associate Editor

Department of Materials Science and Engineering, and

Lawrence Berkeley Laboratory

University of California

Berkeley, California

ROBERT M. FISHER, Associate Editor

U.S. Steel Corporation Research Center

Monroeville, Pennsylvania

Proceedings of the Fifth International Materials Symposium

"The Structure and Properties of Materials-Techniques and Applications of Electron Microscopy," held at the University of California, Berkeley, September 13-17, 1971

University of California Press, Berkeley, Los Angeles, London 
University of California Press

Berkeley and Los Angeles, California

University of California Press, Ltd.

London, England

Copyright (c) 1972, by

The Regents of the University of California

ISBN : $\quad 0-520-02114-2$

Library of Congress Catalog Card Number: 79-175119

Printed in the United States of America 